\title{
Mid- and Long-Term Outcomes of Total Arterial Myocardial Revascularization in Patients Aged 70 Years and Older: A Single-Center Experience
}

\author{
Jill Jussli-Melchers ${ }^{1}$ Bernd Panholzer ${ }^{1}$ Christine Friedrich ${ }^{1}$ Ole Broch ${ }^{2}$ Katharina Huenges ${ }^{1}$ \\ Joachim Cremer $^{1} \quad$ Assad Haneya $^{1}$
}

${ }^{1}$ Department of Cardiovascular Surgery, University Hospital of Schleswig-Holstein, Kiel, Germany

${ }^{2}$ Department of Anaesthesiology and Intensive Care Medicine, University Hospital of Schleswig-Holstein, Kiel, Germany

Address for correspondence jill Jussli-Melchers, Department of Cardiovascular Surgery, University Hospital of Schleswig-Holstein, Campus Kiel, Arnold-Heller-Str. 3, Haus 18, Kiel, Schleswig-Holstein 24105, Germany (e-mail: marka-jill.jussli@gmx.de).

Thorac Cardiovasc Surg 2019;67:444-449.

\begin{abstract}
Keywords

- CABG

- elderly patients

- outcomes

- mortality

- morbidity

- total arterial

myocardial

revascularization
\end{abstract}

Background Patients receiving arterial grafts have superior late survival after coronary artery bypass graft (CABG) surgery. The aim of our study was to evaluate the midand long-term results of total arterial (TA) revascularization in the elderly.

Methods Between January 2005 and December 2012, a retrospective study on age-, gender-, and EuroSCORE-matched patients aged 70 years and older was performed. Altogether, 356 patients who received isolated CABG were assigned to either TA group or control (CON) group.

Results No significant differences were noted in regard to preoperative risk factors. The number of distal anastomoses was significantly higher in the CON group ( $3.6 \pm 0.6$ vs. $2.9 \pm 0.8 ; p<0.001)$. Postoperatively, no significant differences were noted in regard to morbidity or mortality. There were no significant differences in mortality rate at 1 year ( 5.6 vs. $5.2 \% ; p=0.98$ ), or 5 years ( 9.0 vs. $12.1 \% ; p=0.39$ ) between both groups. However, the TA group was associated with significantly higher rate of eventfree survival $(p=0.017)$.

Conclusion This study suggests that TA revascularization is an effective procedure. Lower rates of late cardiac events encourage the use of this concept for the elderly.

\section{Introduction}

The number of patients undergoing surgery due to coronary artery disease has dramatically increased worldwide during the last two decades. Considering the cardiothoracic procedures in 2015 in Germany, every second patient was older than 70 years. ${ }^{1}$ Previous studies have shown that coronary artery bypass graft (CABG) revascularization even for an elderly population is a safe option with better long-term results than percutaneous coronary intervention $(\mathrm{PCI}) .^{2-4}$ The long-term efficacy of arterial revascularization especially of the left internal thoracic artery (LITA) on the left anterior descending (LAD) has been proven in many stu-

received

June 8, 2018

accepted after revision

July 27, 2018

published online

September 15, 2018

dies. ${ }^{5,6}$ Although the harvesting of venous graft material was felt to be easier and several items were developed to improve the quality of the veins, ${ }^{7}$ venous grafts often show occlusion rates of 5 to $10 \%$ per year. ${ }^{8}$ Therefore, long-term durability is often comparably bad. As long-term survival of complete arterial revascularization is mostly higher than venous or combined revascularization, the trend goes to a preference of arterial revascularization especially in the younger population. $^{9}$ There especially bilateral internal thoracic artery (BITA) use seems to improve survival rates. ${ }^{10}$ For elderly patients, the usual revascularization procedure is the LITA on LAD and saphenous vein graft (SVG) on right coronary artery (RCA) and circumflex artery (RCX). ${ }^{11}$ For patients older than

(c) 2019 Georg Thieme Verlag KG Stuttgart · New York
DOI https://doi.org/ 10.1055/s-0038-1669928. ISSN 0171-6425. 
70 years, arterial revascularization is usually used if no venous grafts can be obtained. This can be due to saphenous varicosis, prior vein extraction, or peripheral vascular disease with critically diminished leg perfusion. Yet, as the survival rates presented from other study groups are completely in favor of arterial revascularization for the younger population, ${ }^{12,13}$ the aim of our study was to assess the benefit for patients older than 70 years of total arterial (TA) revascularization compared with conventional CABG surgery.

\section{Materials and Methods}

\section{Patients and Study Design}

At our department, 178 patients aged 70 years and older with an isolated CABG and complete arterial revascularization were enrolled into this retrospective, observational analysis from January 2005 to December 2012. Patients who had off-pump surgery and patients with cardiogenic shock or combined procedures were excluded. Internal mammary arteries were harvested as pedicled conduits in both groups. TA revascularization strategies included LITA plus radial artery (RA) or BITA.

The cohort (TA group) was matched for age, gender, and EuroSCORE with patients who had conventional CABG (LITA plus SVGs) (control [CON] group) during the same period, thus providing two comparable populations of 178 patients in each group. However, it was not possible to match the groups for diabetes mellitus.

Data were collected and extracted from the institution's database and from medical records. The institutional ethics committee approved the study protocol and authorized its conduct and follow-up. Individual patient consent for inclusion in the study was obtained.

The primary end point was the short- and long-term rates of major adverse cardiac and cerebrovascular events (MACCE), a composite of death or a major adverse event (myocardial infarction, stroke, or repeat revascularization). Secondary end points were intraoperative variables (extracorporeal circulation time, cross-clamp time, number of distal anastomoses), and postoperative course (ventilation time, drainage loss, acute renal failure).

The early results of the analysis were presented at the 44th Annual Meeting of the German Society for Thoracic and Cardiovascular Surgery. ${ }^{14}$

\section{Surgical Management}

All patients had a routine general anesthesia. Median sternotomy was applied in all patients. Usually, LITA was harvested while SVG for the CON group and RA for the study population were prepared. After opening of the pericardium, extracorporeal circulation was installed. This was usually done by venous cannulation of the right atrial appendage and arterial cannulation of the aorta. Mild hypothermia $\left(34^{\circ} \mathrm{C}\right)$ was used. Myocardial protection was obtained by antegrade application of cold blood cardioplegic solution. Distal anastomoses were accomplished in a standard fashion using Prolene 8-0. In the study group, RA could be connected directly to the aorta or if sequentially anastomosed to the right and left coronary system as a Y-graft to the LITA. Right internal thoracic artery (RITA) could be connected to the RCX or to the RCA. Rarely, RITA was used as a free graft. In the CON group, SVGs were usually directly connected to the aorta. The surgeries were accomplished by many different surgeons. It can be assumed that complete arterial procedures were performed by more experienced surgeons.

\section{Statistical Analysis}

Statistical analysis was done using the SPSS 18.0 software (SPSS, Chicago, Illinois, United States) and Stata 10 SE (StataCorp., College Station, Texas, United States). Normality of continuous variables was assessed by Lilliefors' test. Values of continuous data are presented as mean \pm standard deviation or as median with range or interquartile range when appropriate. Categorical variables are displayed as frequency distributions $(n)$ and simple percentages (\%). Univariate comparison between the groups for categorical variables was made using the chi-square test and the Fisher's exact test when appropriate. The probability of event-free survival was determined on the basis of survival curves using the Kaplan-Meier's method and compared using the log-rank test. Statistical significance was considered when $p<0.05$.

\section{Results}

Demographic data and clinical presentation are summarized in - Table 1. The patients had a mean age of $75.2 \pm 4.0$ years. Male gender was $68.5 \%$. The EuroSCORE was $10.8 \pm 10.2 \%$. In general, no significant differences were noted between the two groups with regard to preoperative risk factors and clinical presentations. Acute myocardial infarction was $19.1 \%$ in TA group and $16.2 \%$ in the CON group, but not significant. Yet, the rate of patients with diabetes mellitus was significantly higher in the CON group (34.3 vs. $22.5 \%$; $p=0.02$ ).

\section{Operative Data}

In the study group, LITA was used in all cases. In $58.4 \%$, the RITA was obtained. RA graft was taken in 153 patients (86.0\%). In the CON group, LITA was used in all but one patient and RITA was used in six patients (3.4\%). The number of distal anastomoses was significantly lower for the TA group $(2.9 \pm 0.8$ vs. $3.6 \pm 0.6 ; p<0.001)$. Nevertheless, complete revascularization was accomplished to a similar degree in both groups (98.3 vs. 99.4\%). Extracorporeal circulation time was significantly shorter in the TA group (98 \pm 25 vs. $108 \pm 28$ minutes; $p=0.004)$. Cross-clamp time was equal $(65 \pm 19$ vs. $65 \pm 21$ minutes $)$ and did not show significance ( $p=0.97$ ). The intraoperatively administered number of packed red blood cell units was not statistically significant. The intraoperative data can be seen in - Table 2.

\section{Outcomes}

Postoperative data are summarized in - Table 3. No differences in early postoperative and late complications were observed between both groups. The re-exploration rates, due 
Table 1 Demographic data and clinical presentation

\begin{tabular}{|l|l|l|l|}
\hline & $\begin{array}{l}\text { TA group } \\
(\boldsymbol{n}=178)\end{array}$ & $\begin{array}{l}\text { Control } \\
\text { group } \\
(\boldsymbol{n}=178)\end{array}$ & $p$-Value \\
\hline Mean age, y & $75.2 \pm 4.0$ & $75.2 \pm 4.0$ & 1.0 \\
\hline Gender male & $122(68.5 \%)$ & $122(68.5 \%)$ & 1.0 \\
\hline EuroSCORE, \% & $10.8 \pm 10.2$ & $10.8 \pm 10.2$ & 1.0 \\
\hline $\begin{array}{l}\text { Body mass index, } \\
\text { kg/m }\end{array}$ & $27.4 \pm 4.6$ & $27.1 \pm 4.2$ & 0.52 \\
\hline Ejection fraction, \% & $59 \pm 15$ & $61 \pm 14$ & 0.19 \\
\hline $\begin{array}{l}\text { Three-vessel } \\
\text { disease }\end{array}$ & $153(86.0 \%)$ & $161(90.4 \%)$ & 0.25 \\
\hline Urgency of surgery & $117(65.7 \%)$ & $104(58.4 \%)$ & 0.19 \\
\hline \multicolumn{1}{|l|}{ Elective } & $61(34.3 \%)$ & $74(41.2 \%)$ & 0.19 \\
\hline $\begin{array}{l}\text { Urgent/ } \\
\text { emergent }\end{array}$ & $34(19.1 \%)$ & $42(16.2 \%)$ & 0.37 \\
\hline $\begin{array}{l}\text { Acute myocardial } \\
\text { infarction }\end{array}$ & $40(22.5 \%)$ & $61(34.3 \%)$ & 0.02 \\
\hline Diabetes mellitus & $34(19.1 \%)$ & $20(11.2 \%)$ & 0.05 \\
\hline $\begin{array}{l}\text { Peripheral } \\
\text { vascular disease }\end{array}$ & $163(91.6 \%)$ & $156(87.6 \%)$ & 0.29 \\
\hline $\begin{array}{l}\text { Arterial } \\
\text { hypertension }\end{array}$ & $21(11.8 \%)$ & $17(9.6 \%)$ & 0.61 \\
\hline Atrial fibrillation \\
\hline $\begin{array}{l}\text { Chronic obstruc- } \\
\text { tive pulmonary } \\
\text { disease }\end{array}$ & $46.8 \%)$ & $32(18.0 \%)$ & 0.13 \\
\hline
\end{tabular}

Abbreviation: TA, total arterial.

Note: Statistical significance was considered when $p<0.05$. All significant $p$-values were highlighted.

to profuse postoperative bleeding or cardiac tamponade (3.9 vs. $3.4 \% ; p=0.70$ ) and the 48 -hour drainage loss (900 $\mathrm{mL}$ $[500-1,400]$ vs. $600 \mathrm{~mL}[450-1,400] ; p=0.09$ ) did not differ significantly. Consequently, postoperative blood transfusion was comparable between the groups (-Table 2).

Other factors determining intensive care unit (ICU) stay such as temporary dialysis ( 5.6 vs. $6.2 \% ; p=0.98$ ), pulmonary infections ( 6.7 vs. $5.6 \% ; p=0.83$ ), or postoperative neurological complications ( 3.9 vs. $2.8 \% ; p=0.77$ ) were also comparable. Nevertheless, the incidence of postoperative sternal wound infection was higher in the TA group, although this difference was not statistically significant (5.1 vs. $2.8 \%$; $p=0.41)$. The median length of stay in the ICU $\left(2^{2,3} \mathrm{vs}\right.$. 2 days; $\left.^{2,3} p=0.92\right)$ and hospital $\left(9^{7-12}\right.$ vs. 8.5 days; ${ }^{7-12}$ $p=0.45)$ were similar between the groups. The 30-day mortality was lower in the TA group (2.8 vs. $3.9 \% ; p=0.77$ ), but without statistical significance ( - Table 3 ).

Follow-up data are presented in - Table 4 . The mean followup was $8.2 \pm 2.1$ years. Follow-up was $99.4 \%$ (177 patients) for the study population, and $97.2 \%$ (173 patients) for the CON group. There were no significant differences in MACCE rates at 1 year (9.8 vs. $8.1 \% ; p=0.71), 3$ years ( 11.3 vs. $13.3 \%$; $p=0.63$ ), or 5 years ( 15.8 vs. $21.4 \% ; p=0.22$ ) between the groups. Furthermore, there were no significant differences in
Table 2 Intraoperative data

\begin{tabular}{|c|c|c|c|}
\hline & $\begin{array}{l}\text { TA group } \\
(n=178)\end{array}$ & $\begin{array}{l}\text { Control } \\
\text { group } \\
(n=178)\end{array}$ & $p$-Value \\
\hline \multicolumn{4}{|l|}{ Conduits (\%) } \\
\hline $\begin{array}{l}\text { Left internal thoracic } \\
\text { artery }\end{array}$ & $\begin{array}{l}178 \\
(100 \%)\end{array}$ & $\begin{array}{l}177 \\
(99.4 \%)\end{array}$ & \\
\hline $\begin{array}{l}\text { Right internal } \\
\text { thoracic artery }\end{array}$ & $\begin{array}{l}104 \\
(58.4 \%)\end{array}$ & $\begin{array}{l}6 \\
(3.4 \%)\end{array}$ & \\
\hline Radial artery & $\begin{array}{l}153 \\
(86.0 \%)\end{array}$ & $9(5.1 \%)$ & \\
\hline $\begin{array}{l}\text { Saphenous vein } \\
\text { graft }\end{array}$ & $\begin{array}{l}0 \\
(0 \%)\end{array}$ & $\begin{array}{l}178 \\
(100 \%)\end{array}$ & \\
\hline $\begin{array}{l}\text { Number of distal } \\
\text { anastomoses }\end{array}$ & $\begin{array}{l}2.9 \pm 0.8 \\
3(2-3)\end{array}$ & $\begin{array}{l}3.6 \pm 0.6 \\
4(3-4)\end{array}$ & $<0.001$ \\
\hline $\begin{array}{l}\text { Complete } \\
\text { revascularization }\end{array}$ & $\begin{array}{l}175 \\
(98.3 \%)\end{array}$ & $\begin{array}{l}177 \\
(99.4 \%)\end{array}$ & 0.96 \\
\hline $\begin{array}{l}\text { Extracorporeal } \\
\text { circulation time, } \\
\text { min }\end{array}$ & $98 \pm 25$ & $108 \pm 28$ & 0.004 \\
\hline Cross-clamp time, min & $65 \pm 19$ & $65 \pm 21$ & 0.97 \\
\hline Reperfusion time, min & $27 \pm 11$ & $33 \pm 15$ & $<0.001$ \\
\hline $\begin{array}{l}\text { Number of packed red } \\
\text { blood cells, unit }\end{array}$ & $2(0-3)$ & $2(0-4)$ & 0.35 \\
\hline
\end{tabular}

Abbreviation: TA, total arterial.

mortality rates at 1 year ( 5.6 vs. $5.2 \% ; p=0.98$ ), 3 years ( 7.3 vs. $7.5 \% ; p=0.99$ ), or 5 years ( 9.0 vs. $12.1 \% ; p=0.39$ ) between both groups. However, the 5 years repeat revascularization rate (3.3 vs. $6.9 \% ; p=0.15$ ) and the number of patients who need a repeat revascularization due to graft failure (1.1 vs. $4.0 \% ; p=0.10$ ) were lower in the TA group and therefore showed a trend which did not yet reach significance. Furthermore, the Kaplan-Meier's curves revealed that the TA group was associated with significantly higher rates of event-free survival $(p=0.017)($ Fig. 1).

\section{Discussion}

Most of the studies have shown that even for elderly patients, CABG is a better choice than PCI especially in patients with three-vessel disease. ${ }^{15,16}$ After the demonstration of higher life expectancies for younger patients having undergone TA revascularizations, it remains unclear whether elderly patients also benefit from this concept. Thereby it seems to be unimportant which second arterial graft is used as shown in "the RA patency and clinical outcome trial." ${ }^{13,17}$ We therefore investigated if patients older than 70 years also benefit from TA revascularizations.

Age is known to be a risk factor concerning outcome of CABG. ${ }^{18}$ Saran et al demonstrated that age older than 70 years is a high risk factor comparable to ejection fraction below $40 \%$, body mass index more than $30 \mathrm{~kg} / \mathrm{m}^{2}$, chronic lung disease, and diabetes. ${ }^{19}$ To strictly evaluate the revascularization concept in their analysis, the study group was 
Table 3 Postoperative data

\begin{tabular}{|l|l|l|l|}
\hline & $\begin{array}{l}\text { TA group } \\
(\boldsymbol{n}=\mathbf{1 7 8})\end{array}$ & $\begin{array}{l}\text { Control } \\
\text { group } \\
(\boldsymbol{n}=178)\end{array}$ & $p$-Value \\
\hline Inotropic support & $6(3.4 \%)$ & $10(5.6 \%)$ & 0.44 \\
\hline $\begin{array}{l}\text { 48-h drainage } \\
\text { loss, mL }\end{array}$ & $\begin{array}{l}900 \\
(500-1,400)\end{array}$ & $\begin{array}{l}800 \\
(450-1,400)\end{array}$ & 0.09 \\
\hline $\begin{array}{l}\text { Re-exploration for } \\
\text { bleeding }\end{array}$ & $7(3.9 \%)$ & $6(3.4 \%)$ & 0.70 \\
\hline $\begin{array}{l}\text { Number of packed } \\
\text { red blood cells, } \\
\text { unit }\end{array}$ & $2(0-3)$ & $2(0-2)$ & 0.12 \\
\hline $\begin{array}{l}\text { Duration of } \\
\text { ventilation, h }\end{array}$ & $16(11-24)$ & $\begin{array}{l}16 \\
(12-21)\end{array}$ & 0.45 \\
\hline $\begin{array}{l}\text { Postoperative } \\
\text { temporary dialysis }\end{array}$ & $10(5.6 \%)$ & $11(6.2 \%)$ & 0.98 \\
\hline $\begin{array}{l}\text { Postoperative } \\
\text { atrial fibrillation }\end{array}$ & $14(7.9 \%)$ & $6(3.4 \%)$ & 0.11 \\
\hline $\begin{array}{l}\text { Pulmonary } \\
\text { infection }\end{array}$ & $12(6.7 \%)$ & $10(5.6 \%)$ & 0.83 \\
\hline $\begin{array}{l}\text { Deep sternal } \\
\text { wound infection }\end{array}$ & $9(5.1 \%)$ & $5(2.8 \%)$ & 0.41 \\
\hline Stroke & $7(3.9 \%)$ & $5(2.8 \%)$ & 0.77 \\
\hline $\begin{array}{l}\text { Intensive care unit } \\
\text { stay, d }\end{array}$ & $2(2-3)$ & $2(2-3)$ & 0.92 \\
\hline Hospital stay, d & $9(7-12)$ & $8.5(7-12)$ & 0.45 \\
\hline $30-d$ mortality & $5(2.8 \%)$ & $7(3.9 \%)$ & 0.77 \\
\hline
\end{tabular}

Abbreviation: TA, total arterial.

age, gender, body mass index, ejection fraction, and EuroSCORE matched, as well as matched for chronic lung disease. Also, redo surgeries as well as off-pump surgeries were excluded from this study. We are therefore sure to have as few confounders as possible to purely observe the underlying surgical concepts. Yet, we have to admit that it was not possible to match the study group for diabetes mellitus. This might be caused by patient preselection: insulin-dependent diabetes mellitus used to be a contraindication from taking both internal thoracic arteries (ITAs) in general in this center. We have to determine that this strategy is against newer studies, in which it was shown that even diabetic patients benefit from BITAs. ${ }^{20}$ Although in the CON group, $100 \%$ of the patients had venous grafts, and some had RITAs (3.4\%) and RAs (5.1\%) also.

The number of distal anastomoses was significantly lower in the study group $(2.9 \pm 0.8$ vs. $3.6 \pm 0.6 ; p<0.001)$. This might be explained by the lower occurrence of three-vessel disease in the TA group (TA group 86.0\% vs. CON group 90.4\%), which was however not significant. Although the number of patients with three-vessel disease in our study is higher than in other cohorts, that is, 72.6 versus $74.3 \%$ and 75.2 versus $77.7 \% .{ }^{19,21}$ As we perceived the significant difference concerning numbers of distal anastomoses, we re-evaluated our patients and evaluated the completeness of revascularization.
Table 4 MACCE 1, 3, and 4 years after surgery

\begin{tabular}{|c|c|c|c|}
\hline & $\begin{array}{l}\text { TA group } \\
(n=177 ; \\
99.4 \%)\end{array}$ & $\begin{array}{l}\text { CON } \\
\text { group } \\
(n=173 ; \\
97.2 \%)\end{array}$ & $p$-Value \\
\hline MACCE at $1 \mathrm{y}$ & $17(9.8 \%)$ & $14(8.1 \%)$ & 0.71 \\
\hline Death & $10(5.6 \%)$ & $9(5.2 \%)$ & 0.98 \\
\hline Stroke & $8(4.5 \%)$ & $5(2.9 \%)$ & 0.57 \\
\hline Myocardial infarction & 0 & 0 & 0 \\
\hline Repeat revascularization & 0 & 0 & 0 \\
\hline Stroke & $9(5.1 \%)$ & $8(4.6 \%)$ & 0.97 \\
\hline MACCE at $3 \mathrm{y}$ & $\begin{array}{l}20 \\
(11.3 \%)\end{array}$ & $\begin{array}{l}23 \\
(13.3 \%)\end{array}$ & 0.63 \\
\hline Death & $13(7.3 \%)$ & $13(7.5 \%)$ & 0.99 \\
\hline Myocardial infarction & $1(0.6 \%)$ & $1(0.6 \%)$ & 1.0 \\
\hline Repeat revascularization & 0 & $2(1.2 \%)$ & 0.24 \\
\hline MACCE at $5 \mathrm{y}$ & $\begin{array}{l}28 \\
(15.8 \%)\end{array}$ & $\begin{array}{l}37 \\
(21.4 \%)\end{array}$ & 0.22 \\
\hline Death & $16(9.0 \%)$ & $\begin{array}{l}21 \\
(12.1 \%)\end{array}$ & 0.39 \\
\hline Stroke & $10(5.6 \%)$ & $8(4.6 \%)$ & 0.81 \\
\hline Myocardial infarction & $3(1.7 \%)$ & $4(2.3 \%)$ & 0.72 \\
\hline $\begin{array}{l}\text { Repeat } \\
\text { revascularization }\end{array}$ & $6(3.3 \%)$ & $12(6.9 \%)$ & 0.15 \\
\hline Graft failure & $2(1.1 \%)$ & $7(4.0 \%)$ & 0.10 \\
\hline
\end{tabular}

Abbreviations: CON, control; MACCE, major adverse cardiac and cerebrovascular events; TA, total arterial.

There we could not find a significant difference. As the completeness of revascularization particularly for all arterial patients is critical for maximizing the long-term benefits, ${ }^{22}$ we were glad to find revascularization to be completed in $98.3 \%$ of the TA patients and in $99.4 \%$ of the CON patients. This is higher than in other studies, in which completeness of revascularization is described to be $\sim 93.3^{23}$ and $94.7 \%{ }^{21}$ The cross-clamp time was almost identical for both techniques. The number of deep sternal wound infections was higher in the study group ( 5.1 vs. $2.8 \% ; p=0.41$ ). This might have been otherwise, if more diabetic patients would have been in the study group. Data for the risk of sternal wound complications (SWCS) differ and vary between 1.9 and $10.6 \%{ }^{24,25}$ The rates of SWCs for our study groups lie within this range, although it is most likely that for elderly patients, the risk for wound complications is rather higher than for younger patients. The recently published article "Randomized trial of bilateral versus single internal-thoracic-artery grafts" 24 supports the increased risk for wound healing complications after the use of bilateral versus single internal artery grafts. With $58.4 \%$, the percentage of bilateral artery grafting is very high in our study group. In contrast to other studies and multicenter trials, the ITA harvesting was exclusively done in a pedicled manner. It is usually preferred to harvest as small a pedicle as possible with stressing the importance of no touch 


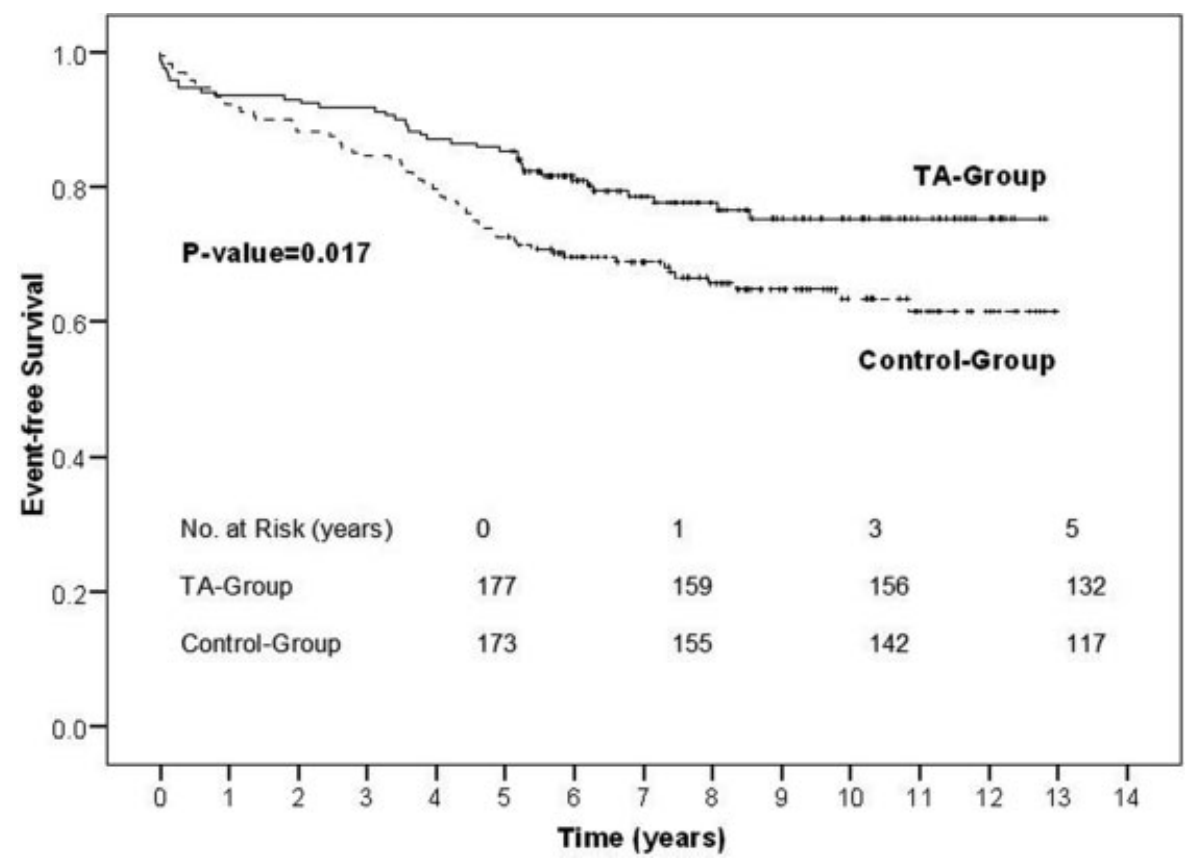

Fig. 1 The 30-day survivors. TA, total arterial.

preparation in our center. This might be a compromise minimizing wound infections while guaranteeing the integrity of the graft material. There is no clear evidence that skeletonized harvesting is superior, but a new meta-analysis of 2,633 shows a significant correlation of the incidence of SWCS with the technique of ITA harvesting. Especially, diabetic patients seem to benefit from this approach (odds ratio: 0.327; 95\% confidence interval: 0.217-0.492; $p<0.001)^{25}$ Although we could not have scheduled angiograms for our patients due to the standards of our ethics committee, our mid- and long-term follow-up data is almost complete (99.4\% for the study population and $97.2 \%$ for the control group) with a mean of $8.2 \pm 2.1$ years. At this time, graft failure of venous grafts usually becomes evident. ${ }^{4,26}$ Strokes were the only aspect more likely to occur in the TA group at 1,3 , and 5 years. Yet, no significance could be determined evaluating any MACCE. In contrast, myocardial infarction, repeat revascularization, and graft failure are more than twice as probable to occur in the CON group. Apart from that, survival rates at 5 years were satisfactory for both groups ( $91 \%$ for the TA group and $87.9 \%$ for the CON group) without reaching significance. These data are slightly better than described by other groups for this age group. ${ }^{21}$ Yet, in contrast to Bisleri et al, who confirmed the superior outcome in TA grafting in patients with "diabetes," we can explicitly not draw any conclusions concerning patients with diabetes in our study.

However, the Kaplan-Meier's curves revealed that the patients having received TA revascularizations have significantly higher rates of event-free survival even with advanced age.

\section{Study Limitations}

Our study has some limitations. The study is a retrospective analysis of data from a single center and the sample size remains small. The patient groups are not randomized or blinded for the used technique because the surgeons determine the methodology based on their preferred technique. No conclusions concerning diabetes mellitus can be drawn as it was not possible to match the study group concerning this item due to a preselection bias. Although complete revascularization was accomplished to a similar degree in both groups, the number of grafts differed significantly between the groups.

\section{Conclusion}

Nevertheless, this study suggests that TA revascularization is a safe and effective procedure in the elderly. Lower rates of late cardiac events encourage the use of TA revascularization for this study population. However, we conclude that randomized, prospective studies are needed to further investigate the role of TA revascularization for elderly patients especially re-evaluating the effects of diabetes mellitus.

\section{References}

1 Beckmann A, Funkat AK, Lewandowski J, et al. German heart surgery report 2016: the annual updated registry of the German Society for Thoracic and Cardiovascular Surgery. Thorac Cardiovasc Surg 2017;65(07):505-518

2 Barnett SD, Halpin LS. Functional status improvement in the elderly following coronary artery bypass graft. J Nurs Care Qual 2003;18(04):281-287

3 Baig K, Harling L, Papanikitas J, et al. Does coronary artery bypass grafting improve quality of life in elderly patients? Interact Cardiovasc Thorac Surg 2013;17(03):542-553

4 van Domburg RT, Kappetein AP, Bogers AJ. The clinical outcome after coronary bypass surgery: a 30-year follow-up study. Eur Heart J 2009;30(04):453-458

5 Loop FD, Lytle BW, Cosgrove DM, et al. Influence of the internalmammary-artery graft on 10-year survival and other cardiac events. N Engl J Med 1986;314(01):1-6 
6 Cameron A, Davis KB, Green G, Schaff HV. Coronary bypass surgery with internal-thoracic-artery grafts-effects on survival over a 15-year period. N Engl J Med 1996;334(04):216-219

7 Emery RW, Solien E, Klima U. Clinical evaluation of the eSVS mesh: First-in-Man trial outcomes. ASAIO J 2015;61(02): 178-183

8 Tatoulis J, Buxton BF, Fuller JA. Patencies of 2127 arterial to coronary conduits over 15 years. Ann Thorac Surg 2004;77(01): 93-101

9 Yi G, Shine B, Rehman SM, Altman DG, Taggart DP. Effect of bilateral internal mammary artery grafts on long-term survival: a meta-analysis approach. Circulation 2014;130(07):539-545

10 Taggart DP, D'Amico R, Altman DG. Effect of arterial revascularisation on survival: a systematic review of studies comparing bilateral and single internal mammary arteries. Lancet 2001;358 (9285):870-875

11 Tatoulis J. Total arterial coronary revascularization-patient selection, stenoses, conduits, targets. Ann Cardiothorac Surg 2013;2 (04):499-506

12 Locker C, Schaff HV, Dearani JA, et al. Multiple arterial grafts improve late survival of patients undergoing coronary artery bypass graft surgery: analysis of 8622 patients with multivessel disease. Circulation 2012;126(09):1023-1030

13 Buxton BF, Shi WY, Tatoulis J, Fuller JA, Rosalion A, Hayward PA. Total arterial revascularization with internal thoracic and radial artery grafts in triple-vessel coronary artery disease is associated with improved survival. J Thorac Cardiovasc Surg 2014;148(04): 1238-1243, discussion 1243-1244

14 44th Annual Meeting of the German Society for Thoracic and Cardiovascular Surgery. Thorac Cardivasc Surg 2015;63(S1):1

15 Hlatky MA, Boothroyd DB, Baker LC, Go AS. Impact of drug-eluting stents on the comparative effectiveness of coronary artery bypass surgery and percutaneous coronary intervention. Am Heart J 2015;169(01):149-154

16 Hannan EL, Zhong Y, Berger PB, et al. Comparison of intermediateterm outcomes of coronary artery bypass grafting versus drugeluting stents for patients $\geq 75$ years of age. Am J Cardiol 2014;113 (05):803-808
17 Hayward PA, Buxton BF. The radial artery patency and clinical outcomes trial: design, intermediate term results and future direction. Heart Lung Circ 2011;20(03):187-192

18 Nicolini F, Fortuna D, Contini GA, et al. The impact of age on clinical outcomes of coronary artery bypass grafting: long-term results of a real-world registry. BioMed Res Int 2017;2017:9829487

19 Saran N, Locker C, Said SM, et al. Current trends in bilateral internal thoracic artery use for coronary revascularization: extending benefit to high-risk patients. J Thorac Cardiovasc Surg 2018;155(06):2331-2343

20 Puskas JD, Sadiq A, Vassiliades TA, Kilgo PD, Lattouf OM. Bilateral internal thoracic artery grafting is associated with significantly improved long-term survival, even among diabetic patients. Ann Thorac Surg 2012;94(03):710-715, discussion 715-716

21 Bisleri G, Di Bacco L, Turturiello D, et al. Improved outcomes of total arterial myocardial revascularization in elderly patients at long-term follow-up: a propensity-matched analysis. Ann Thorac Surg 2017;103(02):517-525

22 Zacharias A, Schwann TA, Riordan CJ, Durham SJ, Shah AS, Habib $\mathrm{RH}$. Late results of conventional versus all-arterial revascularization based on internal thoracic and radial artery grafting. Ann Thorac Surg 2009;87(01):19-26.e2

23 Benedetto U, Caputo M, Patel NN, Fiorentino F, Bryan A, Angelini GD. Long-term survival after off-pump versus on-pump coronary artery bypass graft surgery. Does completeness of revascularization play a role? Int J Cardiol 2017;246:32-36

24 Taggart DP, Altman DG, Gray AM, et al; ART Investigators. Randomized trial of bilateral versus single internal-thoracic-artery grafts. N Engl J Med 2016;375(26):2540-2549

25 Sá MP, Cavalcanti PE, de Andrade Costa Santos HJ, et al. Skeletonized versus pedicled bilateral internal mammary artery grafting: outcomes and concerns analyzed through a meta-analytical approach. Int J Surg 2015;16(Pt B):146-152

26 Farooq V, Serruys PW, Zhang Y, et al. Short-term and long-term clinical impact of stent thrombosis and graft occlusion in the SYNTAX trial at 5 years: Synergy Between Percutaneous Coronary Intervention with Taxus and Cardiac Surgery trial. J Am Coll Cardiol 2013;62(25):2360-2369 